\title{
Epileptic seizures in patients with acute catatonic syndrome
}

\author{
Alberto Primavera, Alessandra Fonti, Paolo Novello, Giuseppe Roccatagliata, \\ Leonardo Cocito
}

\begin{abstract}
Acute catatonic syndrome is a condition that can be caused by a variety of metabolic, neurological, psychiatric, and toxic conditions, including neuroleptic malignant syndrome. Although ictal catatonia as a manifestation of non-convulsive status epilepticus has been described, reference to the occurrence of seizures in patients with acute catatonic syndrome is anecdotal. Twenty nine patients with acute catatonic syndrome were reviewed to identify patients with seizures after the onset of acute catatonic syndrome. Patients were divided into four diagnostic groups: affective (15), schizophrenic (eight), toxic (two), and organic (four). Seizures occurred in four patients (13.8\%): two patients with dystonic seizures had viral encephalitis and schizophrenic disorder respectively; one patient with complex partial seizures had viral encephalitis and one patient with absence status had neuroleptic malignant syndrome. The results indicate the value of EEG in detection of epileptic activity in patients with acute catatonic syndrome, both at onset and in the course of such disturbance, particularly to provide a differential diagnosis between pseudoseizures and neuroleptic-induced acute dystonia.
\end{abstract}

(F Neurol Neurosurg Psychiatry 1994;57:1419-1422)
Kahlbaum ${ }^{1}$ first described catatonia as a syndrome consisting of catalepsy and waxy flexibility, mutism, muscle rigidity, psychotic negativism, and autonomic dysfunctions. Although he considered catatonia as strongly associated with affective illness, he also emphasised the possible association with other diseases, such as alcoholism, epilepsy, malaria, syphilis, and tuberculosis. After the work of Kraepelin and Bleuler, however, there has been a tendency to consider catatonia as a purely psychiatric disorder, commonly associated with schizophrenia. ${ }^{23}$ Recently, many reports have emphasised the association between catatonia and a variety of medical, neurological, and psychiatric conditions $^{4}$ and catatonia has again been regarded as a non-specific entity that has a wide range of organic and psychiatric causes. ${ }^{2}$

\section{Table 1 Causes of acute catatonia}

\begin{tabular}{ll}
\hline & No of patients \\
\hline Affective disorders & $15(51 \cdot 7 \%)$ \\
Major depression & 10 \\
Major depression with psychotic features & 2 \\
Bipolar disorders & 3 \\
Schizophrenic disorders & $8(27 \cdot 6 \%)$ \\
Schizophrenia & 4 \\
Schizophreniform disorders & 3 \\
Brief reactive psychosis & 1 \\
Toxic disorders & $2(6 \cdot 9 \%)$ \\
Neuroleptic malignant syndrome & 2 \\
Organic disorders & $4(13 \cdot 8 \%)$ \\
Encephalitis & 3 \\
Nutritional encephalopathy & 1 \\
Total & 29 \\
\hline
\end{tabular}

Table 2 Clinical details of patients with acute catatonic syndrome and seizures

\begin{tabular}{|c|c|c|c|c|c|c|c|c|c|}
\hline No & $\begin{array}{l}\text { Sexl } \\
\text { age }\end{array}$ & Diagnosis & $\begin{array}{l}\text { Main clinical } \\
\text { findings }\end{array}$ & $\begin{array}{l}\text { Previous psychiatric } \\
\text { disorders }\end{array}$ & $\begin{array}{l}\text { Previous } \\
\text { epilepsy }\end{array}$ & $\begin{array}{l}\text { Type of } \\
\text { seizure }\end{array}$ & Frequency & $A E D$ treatment & $\begin{array}{l}\text { Outcome of } \\
\text { acute } \\
\text { catatonic } \\
\text { syndrome }\end{array}$ \\
\hline 1 & $\mathrm{~F} / 17$ & $\begin{array}{l}\text { Schizophrenic } \\
\text { disorder }\end{array}$ & $\begin{array}{l}\text { Fever } 38^{\circ} \mathrm{C} \\
\text { Tachycardia }\end{array}$ & $\begin{array}{l}\text { Obsessive-compulsive } \\
\text { disorder in childhood }\end{array}$ & No & $\begin{array}{l}\text { Dystonic } \\
\text { seizures }\end{array}$ & Recurrent & Phenobarbitone & $\begin{array}{l}\text { Full } \\
\text { recovery }\end{array}$ \\
\hline 2 & $F / 23$ & Viral encephalitis & $\begin{array}{l}\text { Fever }>40^{\circ} \mathrm{C} \\
\text { Respiratory failure } \\
\text { Serum } \mathrm{CK}=259 \mathrm{U} / 1\end{array}$ & No & No & $\begin{array}{l}\text { Dystonic } \\
\text { seizures }\end{array}$ & Recurrent & Phenobarbitone & Improvement \\
\hline 3 & $F / 22$ & $\begin{array}{l}\text { Neuroleptic } \\
\text { malignant } \\
\text { syndrome }\end{array}$ & $\begin{array}{l}\text { Fever } 39 \cdot 5^{\circ} \mathrm{C} \\
\text { Tachycardia }(150) \\
\text { Serum CK }=2000 \mathrm{U} / 1 \\
\text { Myoglobinuria } \\
\text { Respiratory failure } \\
\text { Adynamic ileus }\end{array}$ & Recent acute psychosis & No & $\begin{array}{l}\text { Absence } \\
\text { status } \\
\text { epilepticus }\end{array}$ & Status & Diazepam & Improvement \\
\hline 4 & $F / 67$ & Viral encephalitis & $\begin{array}{l}\text { Fever } 38^{\circ} \mathrm{C} \\
\text { Respiratory failure }\end{array}$ & $\begin{array}{l}\text { Affective illness } \\
\text { (bipolar) }\end{array}$ & No & $\begin{array}{l}\text { Complex } \\
\text { partial } \\
\text { seizures }\end{array}$ & Recurrent & Carbamazepine & Improvement \\
\hline
\end{tabular}

$\mathrm{CK}=$ creatine kinase $\mathrm{AED}=$ antiepileptic drug 

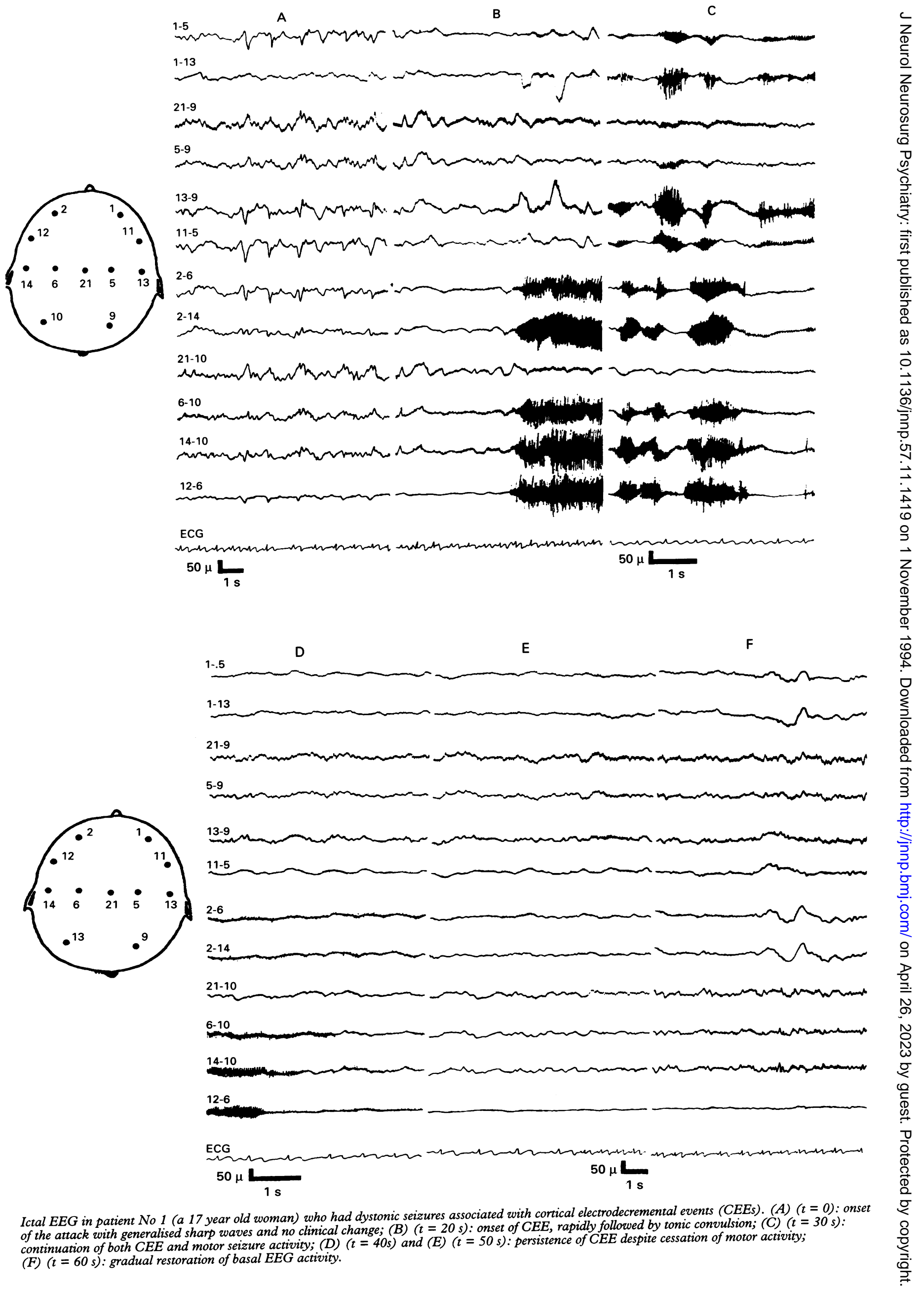
The association between catatonia and epilepsy was emphasised by Kahlbaum in his original monograph, ${ }^{3}$ but it has received scant attention in the modern literature. ${ }^{2}$ Despite a few reports of adequately documented catatonia with concurrent epileptic discharges on the $\mathrm{EEG}^{5-7}$ and of non-convulsive status epilepticus presenting as ictal catatonia, ${ }^{8}$ the reference to the occurrence of seizures in catatonic patients is usually anecdotal. The aim of this study was to investigate the occurrence of seizures in patients with acute catatonic syndrome.

\section{Patients and methods}

Twenty nine patients (11 men, 18 women; age range 15-78; mean age 43.2 (SD 20.0) with acute catatonic syndrome have been retrospectively identified from clinical charts of patients admitted to the Department of Neurology of the University of Genova in the years 1984-92. According to Barnes et al, ${ }^{2}$ the minimum definition of acute catatonic syndrome required that patients rapidly developed, over a period of days or weeks, at least one motor sign (catalepsy, posturing, or waxy flexibility) in combination with at least one of the following clinical signs: (a) negativism, mutism, or stupor; (b) excitement; (c) bizarre repetition behaviour. All patients had a detailed assessment that included physical, neurological, and psychiatric examination, neuroimaging, EEG, CSF examination, and appropriate screening tests for the known metabolic and systemic causes of the syndrome. ${ }^{4}$ Table 1 indicates the likely causes of acute catatonic syndrome in the 29 patients.

The clinical charts of patients with acute catatonic syndrome were reviewed to identify the occurrence of epileptic seizures during the catatonic periods. The diagnosis of seizures was based on the clinical findings and EEG recording.

\section{Results}

Seizures during the catatonic periods occurred in four out of the 29 patients with acute catatonic syndrome $(13 \cdot 8 \%)$. Table 2 summarises the clinical features of these patients.

One patient had complex partial seizures, one patient had absence status epilepticus, and two patients had dystonic seizures associated with cortical electrodecremental events as described by Fariello et al. ${ }^{9}$ The figure shows the EEG findings in one of these patients.

\section{Discussion}

Our series has confirmed that catatonia is a non-specific entity that has a wide range of organic and psychiatric causes, ${ }^{2}$ provided that schizophrenic disorders accounted for only $27 \cdot 6 \%$ of the cases. The frequency of seizures in patients with acute catatonic syndrome $(13 \cdot 8 \%)$ was close to the $16 \%$ reported by Barnes et $a l,{ }^{2}$ although this figure also included seizures occurring outside the catatonic periods. As these rates are definitely higher than those of an age matched general population, a merely coincidental association of seizures and catatonia is unlikely. Seizures were more frequent in patients with organic catatonia, but they occasionally occurred in acute catatonic syndrome due to psychiatric disorders as well. Epileptic seizures in the course of acute catatonic syndrome can be triggered by miscellaneous causes such as hyperpyrexia, liver and renal failure, thromboembolism, neuroleptic drugs, and CNS infections. Critically ill patients with acute metabolic events or drug toxicity may have new onset seizures. ${ }^{10}$ One of our patients had a non-convulsive status epilepticus, as reported by Lim et al. ${ }^{8}$ Absence status epilepticus occurring de novo in adults often results from a conjunction of several epileptogenic factors, such as an excessive amount or withdrawal of psychotropic drugs or toxic or metabolic factors ${ }^{11}{ }^{12}$; all of these conditions are likely to occur in acute catatonic syndrome and can thus account for epileptic seizures in some patients. Such a non-specific mechanism is unlikely, however, to represent the only explanation. One half of patients with epileptic seizures during acute catatonic syndrome had dystonic seizures with cortical electrodecremental events, which are quite unusual in adults. ${ }^{9}$ These seizures are supposed to arise from a subcortical focus, possibly located in the brainstem..$^{91314}$ Subcortical discharges in the EEG have occasionally been reported in patients with catatonic stupor. ${ }^{15}$ The relation between the brainstem (particularly the midbrain) and catatonic states has been a recurring theme, which has received some support from experimental and pathological evidence 3 and, more recently, by neuroimaging. ${ }^{16}$ It can be speculated that both seizures and acute catatonic syndrome might sometimes result from an involvement of the same neural structures, possibly located in the diencephalon, midbrain, and pons. Then epileptic seizures in the course of acute catatonic syndrome are likely to arise from multiple mechanisms, some of which are possibly related to the pathophysiology of catatonia. The reported efficacy of anticonvulsive treatment in catatonia ${ }^{17}$ and, conversely, the relation between periodic electrographic complexes and dopamine insufficiency in neuroleptic malignant syndrome, ${ }^{18}$ indirectly suggest that some common mechanisms may underly both catatonia and seizures.

The possible occurrence of epileptic seizures during acute catatonic syndrome emphasises the importance of EEG monitoring in these patients, both at the onset and in the course of the syndrome. In the absence of an ictal EEG, the occurrence of fits with uncommon features may lead to a wrong diagnosis of non-epileptic attacks, as pseudoseizures and neuroleptic-induced acute dystonia are common in patients with acute behaviour disturbances. ${ }^{19}$ A correct identification of epileptic seizures is essential, however, given the different therapeutic implications. 
This study was partially supported by CNR (Center for Cerebral Neurophysiology, Geneva) and by MURST.

1 Kahlbaum KL. Die Katatonie, oder das Spannungsirresein. Berlin, Klinische Abhandlungen über psychische Krankheiten, 1874 .

2 Barnes MP, Saunders M, Walls TJ, Saunders I, Kirk CA The syndrome of Karl Ludwig Kahlbaum. $\mathcal{f}$ Neurol Neurosurg Psychiatry 1986;49:991-6.

3 Johnson J. Catatonia: the tension insanity. Br $\mathcal{F}$ Psychiatry 1993;162:733-8.

4 Gelenberg AJ. The catatonic syndrome. Lancet 1976:i: 1339-41.

5 Thompson SW, Greenhouse AH. Petit mal status in dults. Ann Intern Med 1968;68:1271-9.

6 Goldensohn ES, Gold AP. Prolonged behavioral disturbances as ictal phenomena. Neurology (Minneap) 1960 ; 10:1-9.

7 Gomez EA, Comstock BS, Rosario A. Organic versus functional etiology in catatonia: case report. 7 Clin Psychiatry 1982;43:200-1.

8 Lim J, Yagnik P, Schraeder P, Wheeler S. Ictal catatonia as a manifestation of nonconvulsive status epilepticus. f Neurol Neurosurg Psychiatry 1986;49:833-6.

9 Fariello RG, Doro JM, Forster FM. Generalized cortical electrodecremental event: clinical and neurophysioogical observations in patients with dystonic seizures. Arch Neurol 1979;36:285-91.

10 Wijdicks EFM, Sharbrough FW. New-onset seizures in critically ill patients. Neurology 1993;43:1042-4.

11 Van Sweden B, Mellerio F. Toxic ictal confusion. F Epilepsy 1988;1:157-63.

12 Thomas $P$, Lebrun $C$, Chatel $M$. De novo absence status epilepticus as a benzodiazepine withdrawal syndrome. Epilepsia 1993;34:355-8.

13 Mutani R, Bergamini L, Fariello R. A case of status epilepticus with tonic expression (so-called "reticular epilepsy"). Epilepsia 1970;11:321-6.

14 Nathanson M, Krumholz A, Biddle D. Seizures of axial structures. Arch Neurol 1978;35:448-52.

15 Johnson J. Stupor: a review of 25 cases. Acta Psychiatr Scand 1984;70:370-7.

16 Joseph AB, Anderson WH, O'Leary DH. Brain stem and vermis atrophy in catatonia. Am $\mathcal{f}$ Psychiatry 1985: 142:352-4.

17 Rankel HW, Rankel LE. Carbamazepine in the treatment of catatonia. Am f Psychiatry 1988;145:361-2.

18 Nelson L, Kramer LD, Locke GE. Periodic EEG complexes, myoclonus, and neuroleptic malignant syndrome [abstract]. Epilepsia 1987;28:607.

19 Lloyd GG. Acute behaviour disturbances. I Neurol Neurosurg Psychiatry 1993;56:1 149-56. 